\title{
Genotype-Phenotype Analysis of Human Frontoparietal Polymicrogyria Syndromes
}

\author{
Xianhua Piao, MD, PhD, ${ }^{1}$ Bernard S. Chang, MD, ${ }^{2}$ Adria Bodell, MS, ${ }^{2}$ Katelyn Woods, BS, ${ }^{1}$ \\ Bruria BenZeev, MD, ${ }^{3}$ Meral Topcu, MD, ${ }^{4}$ Renzo Guerrini, MD, ${ }^{5}$ Hadassa Goldberg-Stern, MD,, 7 \\ Laszlo Sztriha, MD, PhD ${ }^{8}$ William B. Dobyns, MD, ${ }^{9}$ A. James Barkovich, MD, ${ }^{10}$ \\ and Christopher A. Walsh, MD, $\mathrm{PhD}^{2}$
}

\begin{abstract}
Human cerebral cortical polymicrogyria is a heterogeneous disorder, with only one known gene (GPR56) associated with an apparently distinctive phenotype, termed bilateral frontoparietal polymicrogyria (BFPP). To define the range of abnormalities that could be caused by human GPR56 mutations and to establish diagnostic criteria for BFPP, we analyzed the GPR56 gene in a cohort of 29 patients with typical BFPP. We identified homozygous GPR56 mutations in all 29 patients with typical BFPP. The total of 11 GPR56 mutations found represented a variety of distinct founder mutations in various populations throughout the world. In addition, we analyzed five patients with BFPP who did not show GPR56 mutation and found that they define a clinically, radiographically, and genetically distinct syndrome that we termed BFPP2. Finally, we studied seven patients with a variety of other polymicrogyria syndromes including bilateral frontal polymicrogyria, bilateral perisylvian polymicrogyria, and bilateral generalized polymicrogyria. No GPR56 mutation was found in these patients. This study provides a molecular confirmation of the BFPP phenotype and provides the wherewithal for diagnostic screening.
\end{abstract}

Ann Neurol 2005;58:680-687

Polymicrogyria is a cortical malformation characterized by supernumerary, small gyri with abnormal cortical lamination. Harbord and colleagues ${ }^{1}$ first described bilateral frontoparietal polymicrogyria (BFPP; OMIM 606854), an autosomal recessively inherited condition, as an "autosomal recessive neuronal migration defect with nonprogressive cerebellar ataxia." Since this initial description, many cases of BFPP have been reported under five different diagnoses: "autosomal recessive syndrome of pachygyria," "neuronal migration abnormality," "cobblestone lissencephaly," "lissencephaly with cerebellar hypoplasia," and "bilateral frontoparietal polymicrogyria." ${ }^{1-6}$ Using clinical and genetic approaches, we have defined the typical features of BFPP (see Discussion) and linked the BFPP locus to chromosome $16 \mathrm{q} 12-21 .^{6,7}$

Recently, mutations of the GPR56 gene were re- ported in patients with BFPP, mostly in patients originating from the Middle East, except for one founder mutation shared by three families from India, Pakistan, and Afghanistan and another mutation in a nonconsanguineous French Canadian family. ${ }^{8}$ This study summarizes the previously identified BFPP families and describes additional mutational analysis in six new BFPP families with more diverse ethnic backgrounds and in patients with a variety of other bilateral polymicrogyria syndromes.

\section{Subjects and Methods}

\section{Patients}

The newly identified BFPP families comprise four consanguineous families(Table 1; Pedigrees 14-17) and two nonconsanguineous families (see Table 1; Pedigrees 13 and 18). Informed consent was obtained from all patients according
From the ${ }^{1}$ Division of Newborn Medicine, Department of Medicine, Children's Hospital Boston and Harvard Medical School; ${ }^{2}$ Department of Neurology, Howard Hughes Medical Institute, Beth Israel Deaconess Medical Center, Children's Hospital Boston and Harvard Medical School, Boston, MA; ${ }^{3}$ Pediatric Neurologist, Sheba Medical Center, Ramat-Gan, Israel; ${ }^{4}$ Department of Pediatrics, Section of Child Neurology, Hacettepe University Faculty of Medicine, Ankara, Turkey; ${ }^{5}$ Epilepsy, Neurophysiology \& Neurogenetics Unit, Division of Child Neurology and Psychiatry, University of Pisa \& Instituto di Ricovera e Cura a Carattere Scientifico Fondazione Stella Maris, Pisa, Italy; ${ }^{6}$ Epilepsy Center, Schnieder Children's Medical Center, Petach-Tiqva; ${ }^{7}$ Sackler School of Medicine, Tell Aviv University, Tel Aviv, Israel; ${ }^{8}$ Department of Paediatrics, United Arab Emirates University, Al-Ain, United Arab Emirates; ${ }^{9}$ Department of Human Genetics, University of Chicago, Chicago, IL; and ${ }^{10}$ Pediatric Neuroradiology, Department of Radi- ology, University of California, San Francisco, San Francisco, CA.

Received May 6, 2005, and in revised form July 19, 2005. Accepted for publication July 23, 2005.

URLs and accession numbers for data are listed in the Appendix on page 686.

Published online Oct 24, 2005, in Wiley InterScience (www.interscience.wiley.com). DOI: 10.1002/ana.20616

Address correspondence to Dr Walsh, Department of Neurology, Howard Hughes Medical Institute, Beth Israel Deaconess Medical Center, Children's Hospital Boston and Harvard Medical School, 77 Avenue Louis Pasteur, Room 266, Boston, MA 02115.

E-mail: cwalsh@bidmc.harvard.edu 
Table 1. Comparison of Brain Magnetic Resonance Imaging Findings in Patients with and without GPR56 Mutations

\begin{tabular}{|c|c|c|c|c|c|c|c|c|}
\hline \multirow[b]{2}{*}{ Diagnosis } & \multirow[b]{2}{*}{ Pedigrees } & \multirow[b]{2}{*}{$\begin{array}{l}\text { GPR56 } \\
\text { Mutation }\end{array}$} & \multicolumn{3}{|c|}{ Pedigree Comments } & \multicolumn{3}{|c|}{ Brain MRI Findings } \\
\hline & & & Consanguinity & Ethnicity & $\begin{array}{l}\text { Affected } \\
(\mathrm{n})\end{array}$ & PMG & WM & $\begin{array}{l}\text { Brainstem and } \\
\text { Cerebellum }\end{array}$ \\
\hline \multirow[t]{18}{*}{ BFPP } & 1 & Yes & First cousin & Palestinian $^{\mathrm{a}}$ & 3 & FP & Patchy signal change & $\begin{array}{l}\text { Slightly small pons } \\
\text { and superior } \\
\text { vermis }\end{array}$ \\
\hline & 2 & Yes & First cousin & Palestinian $^{a}$ & 2 & FP & Patchy signal change & $\begin{array}{l}\text { Small pons and } \\
\text { superior vermis }\end{array}$ \\
\hline & 3 & Yes & $\mathrm{NC}$ & Pakistani & 2 & FP & $\begin{array}{c}\text { Reduced volume, } \\
\text { periventricular } \\
\text { signal change }\end{array}$ & $\begin{array}{l}\text { Small pons and } \\
\text { superior vermis }\end{array}$ \\
\hline & 4 & Yes & $\mathrm{NC}$ & Indian & 2 & $\mathrm{FP}$ & $\begin{array}{l}\text { Reduced volume, } \\
\text { patchy signal } \\
\text { change }\end{array}$ & $\begin{array}{l}\text { Slightly small pons } \\
\text { and vermis }\end{array}$ \\
\hline & 5 & Yes & First cousin & $\begin{array}{l}\text { Arabic } \\
\quad \text { (Qatar) }\end{array}$ & 2 & FP & Patchy signal change & Small brainstem \\
\hline & 6 & Yes & First cousin & Pakistani & 1 & $\mathrm{FP}$ & Patchy radiolucency & Small cerebellum \\
\hline & 7 & Yes & First cousin & Afghani & 1 & $\mathrm{FP}$ & $\begin{array}{l}\text { Reduced volume, } \\
\text { patchy signal } \\
\text { change }\end{array}$ & $\begin{array}{l}\text { Small pons and } \\
\text { superior vermis }\end{array}$ \\
\hline & 8 & Yes & First cousin & Palestinian $^{\mathrm{b}}$ & 2 & FP & $\begin{array}{l}\text { Reduced volume, } \\
\text { patchy signal } \\
\text { change }\end{array}$ & $\begin{array}{l}\text { Small pons and } \\
\text { cerebellum }\end{array}$ \\
\hline & 9 & Yes & First cousin & Palestinian $^{\mathrm{b}}$ & 1 & FP & $\begin{array}{l}\text { Reduced volume, } \\
\text { frontal subcortical } \\
\text { signal change }\end{array}$ & $\begin{array}{l}\text { Small brainstem } \\
\text { and cerebellum }\end{array}$ \\
\hline & 10 & Yes & Consanguineous $^{c}$ & $\begin{array}{l}\text { Arabic } \\
\qquad{\text { (Bedouin })^{\mathrm{d}}}^{\text {Bed }}\end{array}$ & 3 & FP & $\begin{array}{l}\text { Reduced volume, } \\
\text { patchy signal } \\
\text { change }\end{array}$ & Small vermis \\
\hline & 11 & Yes & First cousin & $\begin{array}{l}\text { Saudi Ara- } \\
\text { bian }\end{array}$ & 1 & FP & $\begin{array}{l}\text { Reduced volume, } \\
\text { patchy signal } \\
\text { change }\end{array}$ & $\begin{array}{l}\text { Small pons and } \\
\text { vermis }\end{array}$ \\
\hline & 12 & Yes & $\mathrm{NC}$ & $\begin{array}{l}\text { French } \\
\text { Canadian }\end{array}$ & 2 & FP & $\begin{array}{l}\text { Reduced volume, } \\
\text { patchy signal } \\
\text { change }\end{array}$ & $\begin{array}{l}\text { Small pons, small/ } \\
\text { dysplastic cere- } \\
\text { bellum }\end{array}$ \\
\hline & 13 & Yes & $\mathrm{NC}$ & $\begin{array}{l}\text { Israeli } \\
\text { Jewish }^{\mathrm{e}}\end{array}$ & 1 & $\mathrm{FP}$ & Patchy signal change & Small vermis \\
\hline & 14 & Yes & First cousin & $\begin{array}{l}\text { Israeli } \\
\text { Jewish }^{\mathrm{e}}\end{array}$ & 2 & FP & Patchy signal change & $\begin{array}{l}\text { Small pons and } \\
\text { vermis }\end{array}$ \\
\hline & 15 & Yes & First cousin & Turkish & 1 & FP & $\begin{array}{l}\text { Severely reduced } \\
\text { volume, patchy } \\
\text { signal change }\end{array}$ & $\begin{array}{l}\text { Small pons and } \\
\text { vermis }\end{array}$ \\
\hline & 16 & Yes & Second cousin & Italian $^{\mathrm{d}}$ & 1 & $\mathrm{FP}$ & $\begin{array}{l}\text { Reduced volume, } \\
\text { patchy signal } \\
\text { change }\end{array}$ & $\begin{array}{l}\text { Slightly small ver- } \\
\text { mis }\end{array}$ \\
\hline & 17 & Yes & First cousin & $\begin{array}{l}\text { Arabic } \\
\text { (UAE) }\end{array}$ & 1 & $\mathrm{FP}$ & $\begin{array}{l}\text { Reduced volume, } \\
\text { patchy signal } \\
\text { change }\end{array}$ & $\begin{array}{l}\text { Slightly small pons } \\
\text { and vermis }\end{array}$ \\
\hline & 18 & Yes & $\mathrm{NC}$ & Hispanic & 1 & FP & $\begin{array}{l}\text { Mildly reduced vol- } \\
\text { ume, patchy sig- } \\
\text { nal change }\end{array}$ & $\begin{array}{l}\text { Slightly small cere- } \\
\text { bellar hemi- } \\
\text { spheres }\end{array}$ \\
\hline \multirow[t]{5}{*}{ BFPP2 } & A1 & $\mathrm{NO}$ & First cousin & $\begin{array}{l}\text { Arabic } \\
\text { (UAE) }\end{array}$ & 1 & $\mathrm{FP}$ & Reduced volume & Normal \\
\hline & A2 & No & $\mathrm{NC}$ & American & 1 & FP & $\begin{array}{l}\text { Markedly reduced } \\
\text { volume }\end{array}$ & $\begin{array}{l}\text { Small brainstem } \\
\text { and vermis }\end{array}$ \\
\hline & A3 & No & $\mathrm{NC}$ & Australian & 1 & $\mathrm{FP}$ & Reduced volume & $\begin{array}{l}\text { Repaired posterior } \\
\text { encephalocele, } \\
\text { normal size } \\
\text { pons and cere- } \\
\text { bellum }\end{array}$ \\
\hline & A4 & No & $\mathrm{NC}$ & Bulgaria & 1 & FP & $\begin{array}{l}\text { Slightly reduced vol- } \\
\text { ume, patchy sig- } \\
\text { nal change }\end{array}$ & Normal \\
\hline & A5 & No & $\mathrm{NC}$ & German & 1 & FP & $\begin{array}{l}\text { Reduced volume, } \\
\text { frontal signal } \\
\text { change }\end{array}$ & Normal \\
\hline
\end{tabular}




\begin{tabular}{|c|c|c|c|c|c|c|c|c|}
\hline \multirow[b]{2}{*}{ Diagnosis } & \multirow[b]{2}{*}{ Pedigrees } & \multirow[b]{2}{*}{$\begin{array}{l}\text { GPR56 } \\
\text { Mutation }\end{array}$} & \multicolumn{3}{|c|}{ Pedigree Comments } & \multicolumn{3}{|c|}{ Brain MRI Findings } \\
\hline & & & Consanguinity & Ethnicity & $\begin{array}{l}\text { Affected } \\
\text { (n) }\end{array}$ & PMG & WM & $\begin{array}{l}\text { Brainstem and } \\
\text { Cerebellum }\end{array}$ \\
\hline \multirow[t]{2}{*}{ BFP } & B1 & No & First cousin & Afghani & 1 & Frontal & Normal & Normal \\
\hline & B2 & No & $\mathrm{NC}$ & Turkish & 1 & Frontal & Reduced volume & Normal \\
\hline $\mathrm{BPP}$ & $\mathrm{C} 1$ & No & $\mathrm{NC}$ & Turkish & 1 & Perisylvian & $\begin{array}{l}\text { Markedly reduced } \\
\text { volume }\end{array}$ & Normal \\
\hline \multirow[t]{4}{*}{ BGP } & D1 & No & $\mathrm{NC}$ & Turkish & 1 & Diffuse & $\begin{array}{l}\text { Mildly reduced vol- } \\
\text { ume }\end{array}$ & Normal \\
\hline & D2 & No & $\mathrm{NC}$ & $\begin{array}{l}\text { Arabic } \\
\text { (UAE) }\end{array}$ & 1 & Diffuse & $\begin{array}{l}\text { Slightly reduced vol- } \\
\text { ume }\end{array}$ & Normal \\
\hline & D3 & No & $\mathrm{NC}$ & German & 1 & Diffuse & Reduced volume & Normal \\
\hline & D4 & No & $\mathrm{NC}$ & American & 1 & Diffuse & $\begin{array}{l}\text { Diffuse signal } \\
\text { change }\end{array}$ & $\begin{array}{l}\text { Small pons and } \\
\text { cerebellum }\end{array}$ \\
\hline
\end{tabular}

${ }^{a}$ These families are from the same village.

${ }^{\mathrm{b}}$ These families are from the same village but distinct from that of Pedigrees 1 and 2.

'This pedigree consists of two nuclear families who are distantly related to one another. One family is a first-cousin marriage and has two affected individuals, and the other set of parents are consanguineous, though their exact relationship is unknown.

${ }^{\mathrm{d}}$ These families have the same mutation, R565W. However, single-nucleotide polymorphism analysis suggested this was a coincidental occurring mutation in two different families.

'These families are Israeli Jewish. Pedigree 13 is a nonconsanguineous family, the father is Karaite descendent, and the mother has a PolishEgyptian origin. Pedigree 14 is pure Karaite descent.

$\mathrm{MRI}=$ magnetic resonance imaging; $\mathrm{PMG}=$ polymicrogyria; $\mathrm{WM}=$ white matter; $\mathrm{BFPP}=$ bilateral frontoparietal polymicrogyria; $\mathrm{FP}=$ frontoparietal; $\mathrm{NC}=$ nonconsanguineous; $\mathrm{UAE}=$ United Arab Emirates; $\mathrm{BFP}=$ bilateral frontal polymicrogyria; $\mathrm{BPP}=$ bilateral perisylvian polymicrogyria; $\mathrm{BGP}=$ bilateral generalized polymicrogyria.

to the guidelines of the Children's Hospital Boston and Beth Israel Deaconess Medical Center. Patients were assessed clinically by at least one of the authors.

A second group of patients also showed similar cortical malformation to that seen in patients with BFPP, but they lacked many of the typical features for BFPP associated with GPR56 mutations (Fig 1A), so we refer to this syndrome as BFPP2. Specifically, Family A1 was a previously reported case. ${ }^{9}$ It is a consanguineous family from the United Arab Emirates with one affected individual (see Table 1). The parents of Families A2 through A5 are nonconsanguineous (see Table 1). To determine the spectrum of malformation caused by GPR56 mutations, we also analyzed the GPR56 gene in several other polymicrogyria syndromes. These patients included two with bilateral frontal polymicrogyria, one with bilateral perisylvian polymicrogyria, and four with bilateral generalized polymicrogyria (see Table 1 and Fig 1B).

\section{Mutation Analysis}

DNA was extracted from peripheral blood with the use of standard methods. The GPR56 gene spans $45 \mathrm{~kb}$ at the genomic level and is composed of 14 exons with a coding region of 2,061bp (GenBank accession number AF106858) from exons 2 to 14 (Fig 2). Primer pairs for amplification of each of the 13 GPR56 coding exons (exons 2-14) were generated from the genomic sequence of GPR56 (University of California, Santa Cruz, Genome Bioinformatics, Santa Cruz, CA; GPR56 [Homo sapiens] range = chr16: 5621145956256445). Exons were sequenced directly by BigDye Terminator sequencing (Applied Biosystems, Foster City, CA). Primer sequences are listed in Table 2.

\section{Results}

Sequence alterations in GPR56 were found in all 29 patients with typical BFPP. Combined with the previ- ous study, a total of 11 different mutations were identified, including 8 missense mutations, 2 splicing mutations, and 1 deletion mutation resulting in a translational frameshift and premature protein termination (Table 3; see Fig 2). All mutations except one missense mutation shared an indistinguishable phenotype, suggesting all are probably null alleles. The C346S mutation found in Families 8 and 9 also causes microcephaly, presumably by affecting proper protein trafficking of GPR56 and possibly that of other proteins (Table 3). ${ }^{6}$

In each pedigree analyzed, the GPR56 mutation always segregated with the disease in the respective families and was not seen in 260 chromosomes from control subjects (70 Europeans and 60 Middle Eastern Arabian individuals). All patients, including those from nonconsanguineous families, carried homozygous mutations. Interestingly, all missense mutations affect regions of the protein predicted to represent the extracellular part of GPR56 (see Fig 2).

No GPR56 mutations were found in 12 patients with a variety of other polymicrogyria syndromes (see Table 1). For example, although the cortical malformation in patients with BFPP2 (Families A1-A5) resembles BFPP (ie, bilateral polymicrogyria that is worst in the frontal and parietal regions with an anterior-toposterior gradient), these pedigrees showed fewer of the diagnostic criteria for typical BFPP, and none of them harbored a mutation in the GPR56 gene (see Table 4). Interestingly, none of them had both white matter abnormalities and hypoplasia of the pons or cerebellar vermis. We thus suggest use of the term BFPP2 to re- 

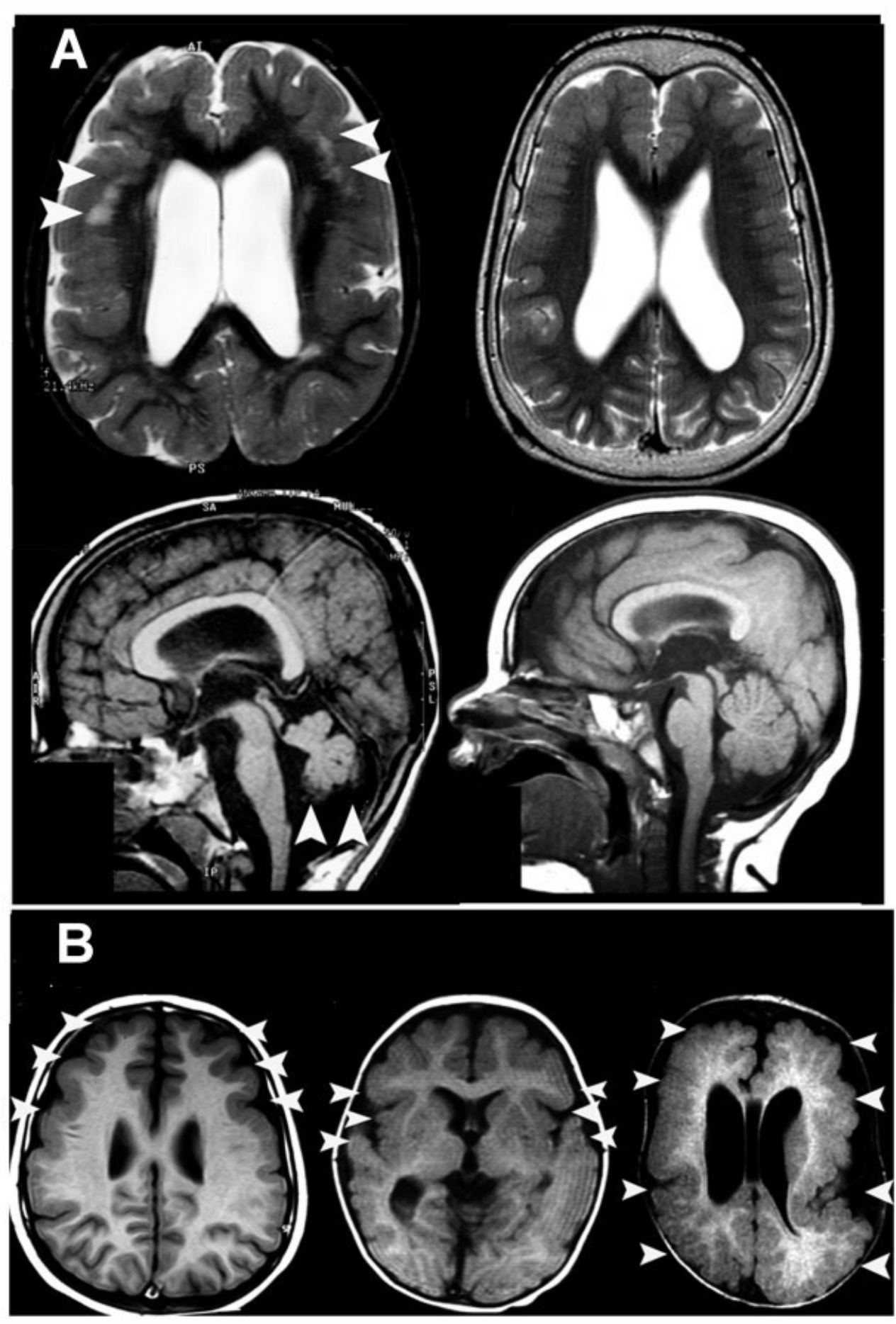

Fig 1. Representative brain magnetic resonance images (MRIs) for different bilateral polymicrogyria syndromes. (A) T2-weighted axial $(a, b)$ and T1-weighted sagittal $(c, d)$ brain MRI of a subject from Pedigree $15(a, c)$, with bilateral frontoparietal polymicrogyria (BFPP) and a GPR56 mutation, and subjects from Pedigrees A3 (b) and A5 (d), with BFPP cerebral cortex but no detectable mutation in GPR56 (BFPP2). The images from the subject with GPR56 mutation demonstrate polymicrogyria in the frontoparietal regions bilaterally, as well as patchy bilateral signal change in the white matter and hypoplasia of the cerebellar vermis and pons (white arrowheads). The images from the subjects with no GPR56 mutation (b, d) demonstrate similar cortical findings but no white matter abnormalities and a normal-size brainstem and cerebellum. (B) T1-weighted axial MRI of a subject from Pedigree B1 (a) with bilateral frontal polymicrogyria, an individual from Pedigree C1 (b) with bilateral perisylvian polymicrogyria, and an individual from Pedigree D3 (c) with bilateral generalized polymicrogyria. White arrowheads indicate regions of polymicrogyria. 


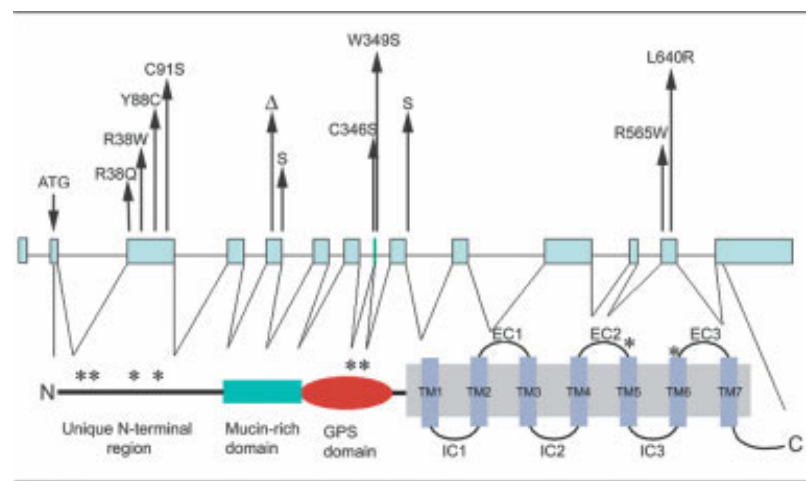

Fig 2. Schematic representation of the GPR56 gene showing genomic structure, known protein domains, and mutations in bilateral frontoparietal polymicrogyria (BFPP) patients. The starting codon ATG is in the second exon. Asterisks indicate positions for the missense mutations: four at the tip of the $N$ terminus (R38Q, R38W, Y88C, and C91S), two in the $G$ protein-coupled receptor proteolytic site (GPS) domain (C346S and W349S), one in the second extracellular loop (R565W), and one in the third extracellular loop (L640R). Open triangle indicates the $7 b p$ deletional mutation. $E C=$ extracellular loop; IC = intracellular loop; $S=$ splicing mutations; $T M=$ transmembrane domain.

fer to patients with BFPP, but who lack some of the diagnostic criteria for typical BFPP, show no mutation in GPR56, or both. However, patients with BFPP2 were not phenotypically homogeneous, which suggests that they are unlikely to represent a single clinical group. Although our coding sequence analysis alone cannot exclude regulatory mutations, the combination of genetic analyses and careful review of brain magnetic resonance images lend further support for a demarcation between classic BFPP and BFPP2. In addition, we performed linkage analysis on Family A1, the only consanguineous family from this group, and found no evidence for linkage to the GPR56 locus (data not shown). Therefore, we conclude that there is a clear genetic separation between patients with classic BFPP and those with BFPP2.

Furthermore, no mutation in GPR56 was found in any of the patients with bilateral frontal polymicrogyria, bilateral perisylvian polymicrogyria, and bilateral generalized polymicrogyria, suggesting the phenotype of GPR56 mutation does not extend to other types of bilateral polymicrogyria syndromes.

\section{Discussion}

Here, we presented clinical phenotype of 29 BFPP patients harboring mutations in GPR56 who share considerable clinical homogeneity with 5 common clinical features and 3 typical magnetic resonance imaging findings identified: (1) mental retardation of moderate to severe degree; (2) motor developmental delay; (3) seizures, most commonly symptomatic generalized epilepsy; (4) cerebellar signs, consisting of ataxia; (5) dysconjugate gaze, presenting variably as esotropia, nystagmus, exotropia, or strabismus; (6) bilateral polymicrogyria with anterior to posterior gradient; (7) bilateral patchy white matter signal changes without specific pattern; and (8) brainstem and cerebellar hypoplasia (see Fig 1A). Mental retardation and motor developmental delay were documented in all patients who had complete medical records available for review, whereas cerebellar signs, dysconjugate gaze, and seizures were presented in 94, 88, and 95\% of BFPP cases, respectively (see Table 4).

The families analyzed here are from different ethnic groups with a wide geographic distribution, including Arabic-speaking Middle Eastern, Pakistani, Indian, Afghani, Canadian, Turkish, Italian, Israeli, and Hispanic American families. However, clinically, they have a homogeneous disease with typical clinical and radiographic features. The identification of mutations in GPR56 in an ethnically diverse group of patients demonstrates the extensive geographic distribution of BFPP.

Table 2. Primer Sequen

\begin{tabular}{lll}
\hline Exons & \multicolumn{1}{c}{ Forward } & Reverse \\
\hline 2 & TCCACACTTGCTTCCCCAC & TGCCAGAAGGAAGGAGTG \\
3 & TAGGTCCTGTCCCCTTCCAT & CCCAGTCCACTTTGCATTTT \\
4 & GTCATGTCAGGGTGGTAGGG & CCCCAGGTGCCAAATTAC \\
5 & CACCATCACCACCGCTTTC & GCGACGGCACTGAGCTTCAG \\
6 & GGATGGGTGTGTGTTGTGT & TGCCTTCTTTCCACCTCTGT \\
7 & TGTGCTGGGAGAGGGTTATC & GAGTCTGGAGGGAGGGAGAG \\
9 & TCTGCCTGGCCTGTAAAGT & GCCATCGCTCTCTCTTCAAA \\
10 & CTTTTGGGGGTGGACACAGT & ATGAAAGTGCTTGCACAGA \\
11 & ACCAGGGACCCCAGGTTAG & CCATGACCGGAGATGTGTG \\
12 & AGGATAGGGGCCATGTATGA & TAGGTGGAGAGGCAGAACCA \\
13 & GTCCAAACTTGGGGGAACTT & GGAGACTGGAACCCAGGTGT \\
\hline
\end{tabular}


Table 3. Mutations in GPR56 Associated with Bilateral Frontoparietal Polymicrogyria

\begin{tabular}{|c|c|c|c|c|}
\hline Pedigrees & Nucleotide Change $^{\mathrm{a}}$ & Exon/Intron & Predicted Protein & Reference \\
\hline 1 & IVS9 $+3 \mathrm{G}>\mathrm{C}$ & Intron 9 & Splicing mutation & Piao and colleagues ${ }^{8}$ \\
\hline 2 & IVS9 $+3 \mathrm{G}>\mathrm{C}$ & Intron 9 & Splicing mutation & Piao and colleagues ${ }^{8}$ \\
\hline 3 & $\mathrm{E} 5-1 \mathrm{G}>\mathrm{C}$ & 5 & Splicing mutation & Piao and colleagues ${ }^{8}$ \\
\hline 4 & 739-746 delCAGGACC & 5 & Frameshift ${ }^{\mathrm{b}}$ & Piao and colleagues ${ }^{8}$ \\
\hline 5 & $112 \mathrm{C}>\mathrm{T}$ & 3 & R38W & Piao and colleagues ${ }^{8}$ \\
\hline 6 & 739-746 delCAGGACC & 5 & Frameshift $^{\mathrm{b}}$ & Piao and colleagues ${ }^{8}$ \\
\hline 7 & 739-746 delCAGGACC & 5 & Frameshift $^{\mathrm{b}}$ & Piao and colleagues ${ }^{8}$ \\
\hline 8 & $1036 \mathrm{~T}>\mathrm{A}$ & 8 & C346S & Piao and colleagues ${ }^{8}$ \\
\hline 9 & $1036 \mathrm{~T}>\mathrm{A}$ & 8 & C346S & Piao and colleagues ${ }^{8}$ \\
\hline 10 & $1693 \mathrm{C}>\mathrm{T}$ & 13 & R565W & Piao and colleagues ${ }^{8}$ \\
\hline 11 & $272 \mathrm{G}>\mathrm{C}$ & 3 & C91S & Piao and colleagues ${ }^{8}$ \\
\hline 12 & $263 A>G$ & 3 & Y88C & Piao and colleagues ${ }^{8}$ \\
\hline 13 & $1046 \mathrm{G}>\mathrm{C}$ & 8 & W349S & This report \\
\hline 14 & $1046 \mathrm{G}>\mathrm{C}$ & 8 & W349S & This report \\
\hline 15 & $113 \mathrm{G}>\mathrm{A}$ & 3 & R38Q & This report \\
\hline 16 & $1693 \mathrm{C}>\mathrm{T}$ & 13 & R565W & This report \\
\hline 17 & $112 \mathrm{C}>\mathrm{T}$ & 3 & R38W & This report \\
\hline 18 & $1919 \mathrm{~T}>\mathrm{G}$ & 13 & L640R & This report \\
\hline
\end{tabular}

All mutations are homozygous, even in nonconsanguineous families.

${ }^{a}$ Base pair counted from starting codon ATG. IVS represents intron; E represents exon; plus sign denotes intronic position 3' of splice junction in donor; and minus sign denotes exonic position $5^{\prime}$ of splice junction in donor. For example, IVS9 +3 means three bases of $3^{\prime}$ of the splice donor junction of intron 9.

${ }^{\mathrm{b}}$ Deletion of $7 \mathrm{bp}$ that alters the translational reading frame, resulting in truncated protein with premature protein termination.

GPR56 encodes a member of the Family B G protein-coupled receptors, which have long $\mathrm{N}$ termini characterized by an extracellular "cysteine box" and hydrophilic, potentially mucin-rich domains. ${ }^{10-12}$ The cysteine box contains four conserved cysteines and two tryptophans arranged in a specific fashion $\left(\mathrm{C}-\mathrm{x}_{2}-\mathrm{W}-\mathrm{x}_{6-16}-\mathrm{W}-\mathrm{x}_{4}-\mathrm{C}-\mathrm{x}_{10-22}-\mathrm{C}-\mathrm{x}-\mathrm{C}\right)$ just before the first transmembrane domain and serves as a cleavage site in some members of this group of $\mathrm{G}$ proteincoupled receptors. ${ }^{13}$ Therefore, the cysteine box was also named the $G$ protein-coupled receptor proteolytic site (GPS) domain. We have shown previously that substitution of one of the four conserved cysteines in GPS domain, C346S, also causes microcephaly. ${ }^{8}$ Here, we show one new mutation in GPR56 that occurs in the GPS domain, which results in the substitution of one of the two conserved tryptophans for serine (W349S) in two Israeli Jewish families. The affected individuals, however, have normal head circumference. Further biochemical analysis of these two mutations may shed light on the function of the GPS domain in this subclass of $G$ protein-coupled receptors.

Mutation W349S was shared by two Israeli Jewish families with no known relationship, but who also shared alleles at flanking single-nucleotide polymorphisms, suggesting that the mutation represents a founder mutation. Pedigree 14 is a Karaite family with consanguineous parents who reside in Israel. The par- ents in Pedigree 13 are nonconsanguineous, with both parents sharing Karaite ancestry. Karaites represent a small Jewish minority who follows tenets of the original form of Judaism.

Mutation R565W occurs in an Italian family (Pedigree 15) and was seen previously in Pedigree 10, an extended Bedouin family. ${ }^{8}$ However, singlenucleotide polymorphism analysis suggested this was a coincidental mutation in two different families without evidence of common haplotype. This mutation is a $\mathrm{C} \rightarrow \mathrm{T}$ transition at a $\mathrm{CpG}$ dinucleotide position. $\mathrm{CpG}$ dinucleotides mutate approximately 10 times faster than other dinucleotides due to cytosine methylation and the subsequent deamination and conversion of $\mathrm{C} \rightarrow \mathrm{T}$, which may explain this recurrent mutation. ${ }^{14}$

In summary, BFPP is an autosomal recessive polymicrogyria syndrome, which was frequently misdiagnosed before the availability of genetic testing and high-resolution neuroimaging. Here, we have presented molecular analysis in a cohort of 29 classic BFPP patients from 18 ethnically diverse families and 12 patients with a variety of other polymicrogyria syndromes. We demonstrated that all predicted pathogenic GPR56 sequence alterations were only found in patients with typical BFPP. GPR56 mutations do not extend to cases of bilateral polymicrogyria that do not adhere to the BFPP cortical distribution, nor to cases with only the cortical 
Table 4. Comparison of Clinical Features and Brain Magnetic Resonance Imaging Findings in Patients with BFPP and BFPP2 Syndromes

\begin{tabular}{|c|c|c|c|c|c|c|c|c|c|c|c|}
\hline \multirow[b]{2}{*}{$\begin{array}{l}\text { Family/ } \\
\text { Patient }\end{array}$} & \multirow[b]{2}{*}{$\mathrm{Age}^{\mathrm{a}} / \mathrm{Sex}$} & \multirow[b]{2}{*}{$\begin{array}{l}\text { GPR56 } \\
\text { Mutation }\end{array}$} & \multicolumn{6}{|c|}{ Clinical Features } & \multicolumn{3}{|c|}{ Brain MRI Findings } \\
\hline & & & $\begin{array}{c}\text { Cognitive } \\
\text { Delay }\end{array}$ & $\begin{array}{l}\text { Motor } \\
\text { Delay }\end{array}$ & $\begin{array}{c}\text { Cerebellar } \\
\text { Signs }\end{array}$ & $\begin{array}{c}\text { Dysconjugate } \\
\text { Gaze }\end{array}$ & Seizures & $\begin{array}{c}\text { Head } \\
\text { Circumference }\end{array}$ & PMG & $\begin{array}{c}\text { WM } \\
\text { Signal } \\
\text { Changes }\end{array}$ & $\begin{array}{c}\text { Brainstem/ } \\
\text { Cerebellum } \\
\text { Hypoplasia }\end{array}$ \\
\hline $1 / \mathrm{IV}-2$ & $14 \mathrm{yr} / \mathrm{F}$ & Yes & Moderate & Yes & Yes & Esotropia & GTC, AS & Normal & $\mathrm{FP}$ & Yes & Yes \\
\hline $1 / \mathrm{IV}-3$ & $9 \mathrm{yr} / \mathrm{F}$ & Yes & Yes & Yes & Yes & Esotropia & $\begin{array}{l}\text { FS, atonic- } \\
\text { drop }\end{array}$ & Normal & $\mathrm{FP}$ & Yes & Yes \\
\hline $1 / \mathrm{IV}-4$ & $7 \mathrm{yr} / \mathrm{M}$ & Yes & Severe & Severe & Yes & Esotropia & FS, GTC & Normal & $\mathrm{FP}$ & Yes & Yes \\
\hline 2/IV-1 & $13 \mathrm{yr} / \mathrm{F}$ & Yes & Severe & Yes & Yes & Esotropia & GTC, atonic & Normal & $\mathrm{FP}$ & Yes & Yes \\
\hline $2 / \mathrm{IV}-4$ & $4 \mathrm{yr} / \mathrm{M}$ & Yes & Severe & Yes & Yes & Esotropia & No & Normal & $\mathrm{FP}$ & Yes & Yes \\
\hline 3/II-1 & $4 \mathrm{yr} / \mathrm{M}$ & Yes & Yes & Yes & NA & Strabismus & $\begin{array}{l}\text { Episodes of } \\
\text { startles }\end{array}$ & Normal & $\mathrm{FP}$ & Yes & Yes \\
\hline $3 / \mathrm{II}-2$ & $13 \mathrm{mo} / \mathrm{F}$ & Yes & Yes & Yes & NA & Strabismus & $\begin{array}{l}\text { Episodes of } \\
\text { startles }\end{array}$ & Normal & $\mathrm{FP}$ & Yes & Yes \\
\hline 4/II-1 & $24 \mathrm{yr} / \mathrm{F}$ & Yes & Yes & Yes & Yes & Exotropia & $\begin{array}{l}\text { Blank epi- } \\
\text { sodes }\end{array}$ & Normal & $\mathrm{FP}$ & Yes & NA \\
\hline $4 / \mathrm{II}-2$ & $20 \mathrm{yr} / \mathrm{F}$ & Yes & Yes & Yes & Yes & No & AS & Normal & $\mathrm{FP}$ & Yes & Yes \\
\hline $5 / \mathrm{IV}-1$ & $13 \mathrm{yr} / \mathrm{M}$ & Yes & Moderate & Yes & Yes & Esotropia & $\begin{array}{l}\text { GTC, myo- } \\
\text { clonic }\end{array}$ & Normal & $\mathrm{FP}$ & Yes & Yes \\
\hline 5/IV-3 & $6 \mathrm{yr} / \mathrm{F}$ & Yes & NA & Yes & Yes & Esotropia & Yes & Normal & FP & Yes & Yes \\
\hline 6/IV-1 & $5 \mathrm{yr} / \mathrm{M}$ & Yes & Severe & Severe & Yes & Esotropia & Generalized & $\begin{array}{l}>98 \text { th per- } \\
\text { centile }\end{array}$ & FP & Yes & Yes \\
\hline 7/V-1 & $8 \mathrm{yr} / \mathrm{M}$ & Yes & Moderate & Yes & NA & Esotropia & NA & NA & FP & Yes & Yes \\
\hline 8/IV-1 & $11 \mathrm{yr} / \mathrm{F}$ & Yes & Yes & Yes & NA & NA & NA & $\begin{array}{l}<2 \text { nd percen- } \\
\text { tile }\end{array}$ & $\mathrm{FP}$ & Yes & Yes \\
\hline 8/IV-4 & $2 \mathrm{yr} / \mathrm{F}$ & Yes & NA & Yes & NA & NA & NA & $\begin{array}{l}<2 \text { nd percen- } \\
\text { tile }\end{array}$ & $\mathrm{FP}$ & Yes & Yes \\
\hline $9 / \mathrm{V}-1$ & $20 \mathrm{mo} / \mathrm{M}$ & Yes & Severe & Yes & Yes & Esotropia & Yes & $\begin{array}{l}<3 \text { rd percen- } \\
\text { tile }\end{array}$ & $\mathrm{FP}$ & Yes & Yes \\
\hline $10 / \mathrm{V}-2$ & $29 \mathrm{yr} / \mathrm{F}$ & Yes & Severe & Yes & NA & No & $\begin{array}{l}\text { GTC, myo- } \\
\text { clonic }\end{array}$ & Normal & FP & Yes & Yes \\
\hline $10 / \mathrm{V}-5$ & $22 \mathrm{yr} / \mathrm{M}$ & Yes & Severe & Yes & NA & Exotropia & $\begin{array}{l}\text { GTC, myo- } \\
\text { clonic }\end{array}$ & Normal & $\mathrm{FP}$ & Yes & Yes \\
\hline 10/IV-3 & $21 \mathrm{yr} / \mathrm{F}$ & Yes & Severe & Yes & No & Yes & $\begin{array}{l}\text { GTC, myo- } \\
\text { clonic }\end{array}$ & Normal & $\mathrm{FP}$ & Yes & Yes \\
\hline 11/II-1 & $7 \mathrm{yr} / \mathrm{F}$ & Yes & NA & NA & NA & NA & NA & NA & FP & Yes & Yes \\
\hline 12/II-1 & $10 \mathrm{yr} / \mathrm{F}$ & Yes & Yes & Yes & Yes & NA & NA & Normal & FP & Yes & Yes \\
\hline $12 / \mathrm{II}-2$ & $2 \mathrm{yr} / \mathrm{M}$ & Yes & Yes & Yes & Yes & Nystagmus & NA & Normal & $\mathrm{FP}$ & Yes & Yes \\
\hline 13/II-1 & $28 \mathrm{mo} / \mathrm{M}$ & Yes & Severe & Yes & Yes & Yes & Yes & Normal & FP & Yes & Yes \\
\hline 14/II-1 & $21 \mathrm{yr} / \mathrm{M}$ & Yes & Yes & Yes & Yes & Nystagmus & Myoclonic & Normal & FP & Yes & Yes \\
\hline $14 / \mathrm{II}-2$ & $12 \mathrm{yr} / \mathrm{M}$ & Yes & Yes & Yes & Yes & Nystagmus & GTC & Normal & FP & Yes & Yes \\
\hline 15/II-1 & $6 \mathrm{yr} / \mathrm{M}$ & Yes & Yes & Yes & NA & NA & Yes & NA & $\mathrm{FP}$ & Yes & Yes \\
\hline 16/II-1 & $9 \mathrm{yr} / \mathrm{M}$ & Yes & Yes & Yes & Yes & Strabismus & Yes & Normal & FP & Yes & Yes \\
\hline $17 / \mathrm{II}-1$ & $1 \mathrm{yr} / \mathrm{M}$ & Yes & Yes & Yes & NA & $\begin{array}{l}\text { Convergent } \\
\text { squint }\end{array}$ & NA & 3rd percentile & $\mathrm{FP}$ & Yes & Yes \\
\hline 18/II-1 & $3 \mathrm{yr} / \mathrm{M}$ & Yes & Yes & Yes & NA & No & Yes & Normal & FP & Yes & Yes \\
\hline A1 & $8 \mathrm{yr} / \mathrm{M}$ & No & Yes & Yes & No & No & myoclonic & 3rd percentile & FP & No & No \\
\hline A2 & $14 \mathrm{mo} / \mathrm{M}$ & No & Yes & Yes & NA & No & $\begin{array}{r}\text { Infantile } \\
\text { spasm }\end{array}$ & Normal & $\mathrm{FP}$ & No & Yes \\
\hline A3 & $11 \mathrm{yr} / \mathrm{M}$ & No & Yes & Yes & NA & Nystagmus & GTC & Normal & $\mathrm{FP}$ & No & No \\
\hline A4 & $30 \mathrm{mo} / \mathrm{M}$ & No & Yes & Yes & No & No & No & $\begin{array}{l}<2 \text { nd percen- } \\
\text { tile }\end{array}$ & $\mathrm{FP}$ & Yes & No \\
\hline A5 & $2 \mathrm{yr} / \mathrm{M}$ & No & Yes & Yes & No & No & No & $\begin{array}{l}<2 \text { nd percen- } \\
\text { tile }\end{array}$ & $\mathrm{FP}$ & Yes & No \\
\hline
\end{tabular}

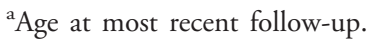

MRI = magnetic resonance imaging; PMG $=$ polymicrogyria; $\mathrm{WM}=$ white matter; $\mathrm{F}=$ female; GTC $=$ general tonic-clonic seizures; AS = absence seizure; $\mathrm{FP}=$ frontoparietal; $\mathrm{FS}=$ febrile seizure; $\mathrm{M}=$ male; $\mathrm{NA}$, information not available.

abnormality but without both white matter and posterior fossa changes, and so we suggest the term BFPP2 to refer to these patients. This study has validated the precise criteria necessary for the accurate diagnosis of BFPP and provides a basis for genetic screening as part of a diagnostic workup.

\section{Appendix}

URLs and accession numbers for data presented herein are as follows: GenBank: http://www.ncbi.nlm.nih.gov/genbank (for GPR56 [H. sapiens] messenger RNA [accession number NM_005682] and GPR56 [H. sapiens] spliced variant [accession number NM_201524]); University of California, Santa 
Cruz (UCSC), Genome Bioinformatics: http://genome.ucsc.edu (for GPR56 [H. sapiens] genomic sequence [accession number NM_005682]); and Online Mendelian Inheritance in Man (OMIM): http://www.ncbi.nlm.nih.gov/omim.

This study was supported by the NIH (National Institute of Neurological Disorders and Stroke, K08 NS045762, X.P.; R37 NS35129, C.A.W.) and the Charles H. Hood Foundation (Child Health Research Grant, X.P. 7/04-6/06). C.A.W. is an Investigator of the Howard Hughes Medical Institute.

We are deeply grateful to the patients and their families for their participation in this study, and to other clinical collaborators who provided information and patient samples not directly involved in this study, specifically Dr I. Scheffer.

\section{References}

1. Harbord MG, Boyd S, Hall-Craggs MA, et al. Ataxia, developmental delay and an extensive neuronal migration abnormality in 2 siblings. Neuropediatrics 1990;21:218-221.

2. Straussberg R, Gross S, Amir J, Gadoth N. A new autosomal recessive syndrome of pachygyria. Clin Genet 1996;50:498-501.

3. Dobyns WB, Patton MA, Stratton RF, et al. Cobblestone lissencephaly with normal eyes and muscle. Neuropediatrics 1996; 27:70-75.

4. Farah S, Sabry MA, Khuraibet A, et al. Lissencephaly associated with cerebellar hypoplasia and myoclonic epilepsy in a Bedouin kindred: a new syndrome? Clin Genet 1997;51:326-330.

5. Sztriha L, Nork M. Bilateral frontoparietal polymicrogyria and epilepsy. Pediatr Neurol 2000;22:240-243.
6. Chang BS, Piao X, Bodell A, et al. Bilateral frontoparietal polymicrogyria: clinical and radiological features in 10 families with linkage to chromosome 16. Ann Neurol 2003;53: 596-606.

7. Piao X, Basel-Vanagaite L, Straussberg R, et al. An autosomal recessive form of bilateral frontoparietal polymicrogyria maps to chromosome 16q12.2-21. Am J Hum Genet 2002;70:10281033.

8. Piao X, Hill RS, Bodell A, et al. G protein-coupled receptordependent development of human frontal cortex. Science 2004; 303:2033-2036.

9. Sztriha L, Nork M. Bilateral symmetrical frontoparietal polymicrogyria. Eur J Paediatr Neurol 2002;6:229-232.

10. Stacey M, Lin HH, Gordon S, McKnight AJ. LNB-TM7, a group of seven-transmembrane proteins related to family-B G-proteincoupled receptors. Trends Biochem Sci 2000;25:284-289.

11. Fredriksson R, Lagerstrom MC, Hoglund PJ, Schioth HB. Novel human G protein-coupled receptors with long $\mathrm{N}$-terminals containing GPS domains and Ser/Thr-rich regions. FEBS Lett 2002;531:407-414.

12. Fredriksson R, Gloriam DE, Hoglund PJ, et al. There exist at least 30 human G-protein-coupled receptors with long Ser/Thrrich N-termini. Biochem Biophys Res Commun 2003;301: 725-734.

13. Krasnoperov V, Lu Y, Buryanovsky L, et al. Post-translational proteolytic processing of the calcium-independent receptor of alpha-latrotoxin (CIRL), a natural chimera of the cell adhesion protein and the $G$ protein-coupled receptor. Role of the $G$ protein-coupled receptor proteolysis site (GPS) motif. J Biol Chem 2002;277:46518-46526.

14. Coulondre C, Miller JH, Farabaugh PJ, Gilbert W. Molecular basis of base substitution hotspots in Escherichia coli. Nature 1978;274:775-780. 